\title{
Hans Morgenthau and The Purpose of American Politics Richard Ned Lebow
}

$\mathrm{H}$ ans Morgenthau's The Purpose of American Politics was published in 1960, at the end of the Eisenhower administration and on the eve of Morgenthau's first attempt to author a book primarily about the United States, exploring opposing American political traditions and their implications for foreign policy. In the process, he comments on past and present domestic and foreign crises and the ways they are refracted by Hamiltonian and Jeffersonian understandings of the national purpose. Morgenthau is drawn to the Hamiltonian approach, which is realist in its assumptions; but he is nevertheless sympathetic to the Jeffersonian emphasis on freedom, which differentiates America, in his view, from other countries. The book represents Morgenthau's coming to terms with America, lauding the purposes for which the country was founded, but the overall argument is pessimistic. Morgenthau contends that America has lost its sense of purpose, on the home front and abroad. When read next to his Scientific Man vs. Power Politics, published in 1946, the book reveals a significant shift in his intellectual and political orientations. ${ }^{1}$

\section{A Man of His Time}

The Purpose of American Politics is very much a book of the late 1950 in terms of the outlook of the author and the issues it addresses: the cold war, and specifically the missile gap; the economic challenge of the Soviet Union; alliances and foreign aid; and nuclear weapons and deterrence. This is equally true of the home front, where Morgenthau offers a version of "the end of ideology," voices optimism about closing the gap between rich and poor, and expresses concern over growing materialism, corporate influence, and McCarthyism. The Soviet Union is portrayed as unremittingly aggressive and the United States as a beacon to the

Ethics \& International Affairs, 30, no. 1 (2016), pp. 55-62.

(c) 2016 Carnegie Council for Ethics in International Affairs

doi:10.1017/So892679415000611 
world. There is much discussion about inequality, but entirely in economic terms. The plight of African-Americans or women is never mentioned, and there is a passing reference to Native Americans as "redskins."

If Morgenthau is a man of his time, he nevertheless transcends parochial perspectives, treating domestic and foreign policy as components of a holistic analysis. While limited to America, The Purpose of American Politics is comparative in the same sense as Tocqueville's Democracy in America, as it is deeply informed by his European upbringing and experiences. Like Tocqueville's account, its core arguments are rooted in political philosophy. Both Tocqueville and Morgenthau were motivated by personal and political objectives; and although both were concerned with the purpose of America, they produced different kinds of works. Tocqueville offers a profound analysis of America and its likely future, with equality and its consequences as his central theme, and with a mix of optimism and pessimism. Morgenthau attempts to produce a similarly profound analysis, also on the theme of equality, but writes what has rightly been described as a jeremiad. ${ }^{3}$ He contends that something central to our lives has been lost, can be recovered, and recovery can lead to a better future. The book also resembles a jeremiad in tone, striking a register somewhere between detached analysis and sermon. Perhaps this explains why Democracy in America became what Thucydides would describe as a "possession for all time," while The Purpose of American Politics sold well when published but is read today by only a small number of international political theorists.

\section{At Home}

Morgenthau laments that the purpose of America has been reduced to "equality at home and safety abroad." These goals lack substantive content and say nothing about "the transcendent purpose" for which equality and safety are sought. America has a purpose, in fact multiple purposes, that derive from the conceptions of order that motivated the country's early settlers and were encouraged by its natural environment. They are less substantive than procedural, and consist of "a peculiar way of thinking and acting in the social sphere, and a peculiar conception of the relations between the individual and society." ${ }^{4}$ Equality in freedom was the incentive that drove millions of Europeans to American shores. In lieu of fixed stations in life, people could achieve a status commensurate with their skills and hard work. They were also free to express their opinions and collectively to 
remake the social order in accord with their needs. ${ }^{5}$ Loyalty to this purpose constitutes the core of American identity, and distinguishes it from other countries where social order is based on inheritance. Only in America does a person choose his country. ${ }^{6}$

Morgenthau contrasts the Hamiltonian and Jeffersonian traditions. Jeffersonians valued weak national government and considered such weakness as essential to preserving freedom. By contrast, Hamiltonians favored strong government as essential to security and economic development. ${ }^{7}$ In The Purpose of American Politics Morgenthau, a committed Hamiltonian, restates the case for a strong government, which he believes is essential for the kinds of reforms necessary to compete with the Soviet Union. Of equal importance, governmental intervention in the economy is critical to sustaining vertical and horizontal mobility. Instead, he says America is witnessing a "new Feudalism"-the paradoxical condition of a government with increasing powers but with a corresponding decline in the power of those charged with governing by the Constitution. The decline is due to the fragmentation of power within government, especially in the executive branch, which has been divided and subdivided into a plethora of agencies. The president cannot supervise them effectively, and the Congress cannot supervise the Executive. The result is government behind closed doors that gives excess power to businesses and their lobbyists, and this, Morgenthau believes, will ultimately produce inequality and reduce upward mobility. ${ }^{8}$

Following Tocqueville, Morgenthau recognized that freedom and equality do not guarantee a healthy polity. This requires individual dynamism and independence. Throughout the 1950 s he worried that these personal traits were diminishing (though the rise of the civil rights and anti-war movements would restore his optimism). The Janus-faced nature of democracy was evident to the authors of The Federalist Papers and to Tocqueville-both warning of the tyranny of the majority. For James Madison, this arose from majority passions that led to the trampling of the rights of the minority. For Tocqueville, it arose from equality: as citizens become more equal and alike they develop "an almost unlimited trust in the judgment of the public." The very equality that makes them independent of their fellow citizens leaves them "isolated and without defense against the action of the greatest number." In the absence of meaningful debate, politicians who advocate unlimited expansion of popular power can easily mislead citizens. Instead of restraining officials, elections can become the vehicle for destroying real democracy. ${ }^{10}$ 
In The Purpose of American Politics Morgenthau offers a variant of the tyranny of majority and a somewhat different and more conservative remedy. American equality has led to what he calls "equality without distinction," whereby all opinions and cultural products are considered equal. The standards for excellence in politics, art, literature, and ethics are fast disappearing. ${ }^{11}$ The vox populi becomes the accepted arbiter of everything, and it often represents the lowest common denominator. Conformity becomes the most powerful social norm. ${ }^{12}$ Morgenthau is optimistic about civil rights, but deeply pessimistic about the survival of democracy in the long term.

\section{Abroad}

Morgenthau's analysis of the cold war derives in part from the realist theory he developed in Politics Among Nations, ${ }^{13}$ whereby he sees the Soviet Union as an "imperialist" power intent on upsetting the territorial status quo. Thus, it is essential to balance against it and to work with other status quo powers, especially those most directly threatened. Consequently, the United States must maintain necessary conventional and nuclear forces to deter the Soviet Union or make war against it, if necessary.

Politics Among Nations was intended to offer general principles to guide foreign policy and its analysis. The application of those principles is always context dependent in a double sense: context determines if they will be applied and, if so, how they will be applied. ${ }^{14}$ The Purpose of American Politics is all about context. Morgenthau believes that it is possible to check the Soviet Union, but worries that Americans lack the commitment to do so. He is also concerned that allies will exploit American economic and military aid for parochial ends and weaken anti-Soviet coalitions while increasing the risk of regional conflict.

Morgenthau's application of principles to foreign policy is revealing. Balancing can never be applied in an objective manner because it depends, in the first instance, on the identification of an imperialist power to balance against and, second, on other states willing to participate in the balancing. Morgenthau has no doubts about Moscow's aggressive intentions; like other cold war hawks he treats-implicitly in his case-Khrushchev's Soviet Union as the successor to Hitler's Germany. Its goal is world conquest, and its leaders are willing to use force, not only subversion, to achieve it. Given the ends that communist leaders seek-and Morgenthau treats Russia, China, and Vietnam as a monolithic 
bloc-the United States must "reshape our economic, educational, and governmental systems on radically new lines." He calls for an "unprecedented and concerted national effort" toward these ends in a time of peace, without which successful competition will be impossible. ${ }^{15}$ This is because the communist adversary is "in its totality, directed single-mindedly by a totalitarian government." ${ }^{16}$

There is no nuance in Morgenthau's depiction of the Soviet Union and no recognition that its leaders might have more limited objectives and be at least as keen as their American counterparts on avoiding war, given their experience in World War II. Morgenthau fails to recognize or acknowledge that Soviet domestic and foreign policies underwent considerable evolution in the seven years following Stalin's death in 1953. Nor does he display any sensitivity to what John Herz has called "the security dilemma": how efforts by states to protect themselves against threats tend to confirm the worst-case fears of leaders of the states whom their preparations are directed against, who in turn may act in ways that ratchet up tensions. ${ }^{17}$

Morgenthau acknowledges that nuclear weapons create a novel situation for theorists and policymakers alike. American reliance on "massive retaliation" has reduced the credibility of any threat to use its arsenal against another nuclear power, because all-out nuclear war in these circumstances is tantamount to suicide. Overreliance on massive retaliation has also reduced the country's ability to fight more limited wars or to take advantage of Soviet weaknesses. Despite the Eisenhower administration's proclamation of a "roll-back" strategy in Eastern Europe, Morgenthau complains, the United States stood by helplessly when Soviet tanks and troops crushed the East German uprising of 1953 and marched into Hungary in $1956 .{ }^{18}$

\section{WORLD ORDER}

For Morgenthau, the "existential threat" that nuclear weapons pose to all nations cannot be addressed within the framework of sovereign states. The only solution is to transfer the control of nuclear weapons to a supranational authority. U.S. efforts toward this goal, most notably the Acheson-Baruch-Lilienthal Proposal of 1946 and the 1958-1960 negotiations for a cessation of atomic testing, failed. The Soviet Union has remained unalterably opposed to supranational control of nuclear weapons, Morgenthau argues, because its leaders believe, not unreasonably, that it would put it at a comparative disadvantage. Consequently, he urges American 
leaders to be more compromising in their demands and to accept tolerable risks when it comes to nuclear agreements and inspection on the assumption that half a loaf is better than none. ${ }^{19}$

Morgenthau follows his treatment of the nuclear threat with a discussion of world order. Survival is a first-order priority, but we need a reason to survive. Retreat into isolation is no longer feasible, so the purpose of survival must assume an important international dimension. The United States responded to postwar challenges by applying its defining domestic principle of equality to foreign policy and treating its allies as equals in lieu of establishing a hierarchical order. Application of this principle, however, "has resulted in disintegration and anarchy." NATO is a "rather loosely knit" and "stagnating" alliance. Foreign aid given to allies treated as equals merely strengthened the conservative political and military forces in favor of the status quo in these countries and allowed the communists to present themselves as favoring the forces of progress. Washington should instead use its power to impose its anti-imperialist tradition on these countries by using aid as a vehicle to bring about democratic change. ${ }^{21}$ Morgenthau shows no recognition that such a policy might readily be condemned as neo-imperialism.

Morgenthau's preference for hierarchical alliances is motivated by a concern for American credibility in Europe and democratic change elsewhere in the world. He fails to consider the downside of such alliances, of which the Warsaw Pact offers a prime example. His claim that the United States treats its allies as equals because of its domestic experience and anti-imperialism tradition finds recent resonance in the claim of John Ikenberry, who argues that the United States differed from previous hegemons, and from its Soviet rival, in establishing a more consensual system of alliances and economic arrangements in which it was merely primus inter pares. However, unlike Morgenthau, Ikenberry regards this kind of restraint as a good thing. ${ }^{22}$ Morgenthau and Ikenberry alike have been criticized for overstating the case. Certainly, NATO and other American alliances were never as hierarchical as the Warsaw Pact, but the United States never hesitated in pushing its interests and at times acted unilaterally when it could not build a consensus for its policies.

A related and striking feature of The Purpose of American Politics is Morgenthau's scorn for the Eisenhower presidency. To his mind, Eisenhower allowed government to fragment, undermining his own power to impose order and consistency on American foreign policy. He adopted the wrong standards for 
government by bowing to public opinion rather than holding fast to the national interest. He failed to rise to the challenge of the Soviet military threat and remained passive in response to Sputnik. Morgenthau advocates the kind of military buildup that the Kennedy administration would later put into effect. ${ }^{23}$ In retrospect, Eisenhower seems a better president than Morgenthau and other critics surmised at the time. ${ }^{24} \mathrm{He}$ ended the Korean War, shunned intervention in Vietnam, was never intimidated or unduly worried about the Soviet Union, refused to escalate the arms race in a dramatic way, and warned of the growing power of the military-industrial complex in his farewell address.

Indeed, in the 1960 s and 1970 s Morgenthau came to sound more like Eisenhower. He reversed his stance on nuclear policy and spoke out against the arms race and nuclear strategies based on war-fighting as opposed to existential deterrence. He became an advocate of restraint and criticized demonization of the Soviet Union. Above all, he was a vocal opponent of U.S. intervention in Indochina, which he described as contradictory to American interests and traditions. $^{25}$

\section{CONCLUSION}

The Purpose of American Politics is not a book that has endured, with good reason. Notably, it fails to develop the links between the theory and practice of foreign policy in convincing ways; its author would shortly disavow some of his key positions concerning nuclear weapons and strategy; and its predictions were off the mark. Despite the absence of supranational control of nuclear weapons, the superpowers avoided war, reached a series of arms-control agreements, and brought their conflict to a peaceful resolution. NATO has not collapsed but has prospered.

Morgenthau's domestic arguments fare only a little better. The standards Morgenthau wants to uphold were historically associated with traditional, even aristocratic hierarchies. In Britain and Germany they sustained culture and respect for learning. Their negative features are well enough known to require no elaboration. Morgenthau was right in thinking that freedom and equality were central to the American purpose and self-definition of its citizens. The sexual revolution - which embodied both values-was just beginning when his book appeared; the civil rights movement was already underway. Commitment to freedom and equality would remove remaining restrictions on Catholics and Jews, go a long way toward alleviating formal and informal oppression of African-Americans, and 
inspire feminism and the push for equal rights of every kind for women and, more recently, for homosexuals.

In contrast to Tocqueville, who understood contemporary trends and their possible futures, Morgenthau was relatively blind to the changes going on around him and the social upheaval they would produce in the decade after his book appeared. This revolution can be described at least in part as a renewal of the American purpose in exactly the manner Morgenthau desired. Social change is always both for better and for worse to varying degrees, but Morgenthau was sensitive only to the latter. But this too would change, and very rapidly, as he became a great supporter of civil rights-even allowing this grateful research assistant to take time off to participate in civil rights demonstrations.

\section{NOTES}

${ }^{1}$ See Hartmut Behr's essay in this issue.

${ }^{2}$ Hans J. Morgenthau, The Purpose of American Politics (New York: Knopf, 1960), p. 134.

${ }^{3}$ On this point, see Vibeke Schou Tjalve, Realist Strategies of Republican Peace: Niebuhr, Morgenthau, and the Politics of Patriotic Dissent (New York: Palgrave Macmillan, 2008).

${ }^{4}$ Morgenthau, Purpose of American Politics, pp. 19-21.

${ }^{5}$ Ibid., pp. $24-30$, on horizontal and vertical mobility.

${ }^{6}$ Ibid., p. 56.

7 Ibid., pp. $77-83,266-68$.

${ }^{8}$ Ibid., pp. 219, 274-92, 302.

9 Alexis de Tocqueville, Democracy in America, Harvey C, Mansfield and Debra Winthrop, ed. and trans. (Chicago: University of Chicago Press, 2000), II.1.2., pp. 409-10.

${ }^{10}$ Alexander Hamilton, James Madison, and John Jay, The Federalist with Letters of "Brutus," Terence Ball, ed. (Cambridge: Cambridge University Press, 2003), esp. no. 10; and Tocqueville, Democracy in America, esp. I, 2.2, p. 169.

${ }^{11}$ Morgenthau, Purpose of American Politics, pp. 237-43.

${ }^{12}$ Ibid., pp. 61-63, 243-45, 249-52.

${ }^{13}$ Hans J. Morgenthau, Politics Among Nations (New York: Knopf, 1948).

${ }^{14}$ Richard Ned Lebow, The Tragic Vision of Politics: Ethics, Interests, and Orders (Cambridge: Cambridge University Press, 2003), ch. 6.

${ }^{15}$ Morgenthau, Purpose of American Politics, p. 166.

${ }^{16}$ Ibid., p. 332.

${ }^{17}$ John Herz, "Idealist Internationalism and the Security Dilemma," World Politics 2, no. 2 (1950), pp. 171-201

${ }_{18}$ Morgenthau, Purpose of American Politics, pp. 167-77, 528-29.

19 Ibid., pp. 171-77.

${ }^{20}$ Ibid., p. 185

${ }^{21}$ Ibid., pp. 188-96.

${ }^{22}$ G. John Ikenberry, After Victory: Institutions, Strategic Restraint, and the Rebuilding of Order After Major Wars (Princeton, N.J.: Princeton University Press, 2001).

${ }^{23}$ Morgenthau, Purpose of American Politics, pp. 206-209, 328-29.

${ }^{24}$ Fred Greenstein, The Hidden-Hand Presidency: Eisenhower as Leader (Baltimore, Md.: Johns Hopkins University Press, 1994) for the beginning of Eisenhower revisionism.

${ }^{25}$ Louis B. Zimmer, The Vietnam War Debate: Hans J. Morgenthau and the Attempt to Halt the Drift into Disaster (Lanham, Md.: Lexington Books, 2011); and Campbell Craig and Fredrik Logevall, America's Cold War: The Politics of Insecurity (Cambridge, Mass.: Harvard University Press, 2009). 